\title{
Pedagogias culturais em realizações de cineastas Mbyá-Guarani ${ }^{1}$
}

\author{
CACHOEIRA, Luiz Antônio Lima² \\ $B O N I N$, lara Tatiana ${ }^{3}$
}

\section{RESUMO}

O cinema indígena vem sendo conformado a partir de um amplo conjunto de narrativas fílmicas cuja realização resulta da ação direta de membros de distintas etnias indígenas brasileiras, com apoio de instituições voltadas para a produção audiovisual autoral. Muitas destas produções têm sido premiadas e exibidas no Brasil e no exterior, acompanhadas, algumas vezes, de sessões de debate com os próprios cineastas e realizadores. Considerando que o cinema indígena dinamiza estéticas singulares, marcadas pelas formas de pensar e de narrar de um povo indígena, no presente texto focalizam-se narrativas cinematográficas feitas por membros do povo Mbyá-Guarani no âmbito do projeto Vídeo nas Aldeias. O objetivo é analisar significados de territorialidade constituídos nos filmes "Desterro Guarani" e "Tava, a casa de pedra", dos cineastas Mbyá-Guarani Patrícia Ferreira (Keretxu) e Ariel Duarte.

Cinema indígena. Pedagogias Culturais. Relações Étnico-raciais.

\section{Cultural pedagogies in Mbyá-Guarani filmakers}

\section{ABSTRACT}

The Indigenous cinema has been shaped after a wide set of film narratives coming from different Brazilian Indigenous ethnic groups' action held by institutions aiming at authorial audiovisual production. Many of these productions were rewarded and exhibited abroad sometimes in debates with the very filmmakers and directors. Considering that the Indigenous cinema fosters singular aesthetics, marked by typical Indigenous ways of thinking and

\footnotetext{
${ }^{1}$ O presente trabalho foi realizado com apoio do CNPq, Conselho Nacional de Desenvolvimento Científico e Tecnológico, e da Capes, Coordenação de Aperfeiçoamento de Pessoal de Nível Superior.

${ }^{2}$ Mestre em Educação pelo Programa de Pós-Graduação em Educação da Universidade Luterana do Brasil; Especialização em História da Arte pelo Centro Universitário Claretiano; Graduação em Bacharelado em História pela Universidade Luterana do Brasil. E-mail: lalcachoeira@gmail.com. Lattes: http://lattes.cnpq.br/9082476995035254. ORCID: https://orcid.org/0000-0002-1437-1756.

${ }^{3}$ Doutora em Educação pela Universidade Federal do Rio Grande do Sul; Professora do Programa de Pós-Graduação em Educação da Universidade Luterana do Brasil, Bolsista Produtividade do CNPq (PQ 2). E-mail: itnonin@gmail.com. Lattes: http://lattes.cnpq.br/7925856179663459. ORCID: https://orcid.org/0000-0001-7156-8849.
} 
narrating, this work has focussed on cinema narratives by Mbyá-Guarani members in the project called Vídeo nas Aldeias (something like 'Video in Indigenous Villages'). The objective is to analyse meanings of territoriality in 'Desterro Guarani' and 'Tava, a casa de pedra' by Mbyá-Guarani filmmakers Patrícia Ferreira (Keretxu) and Ariel Duarte.

Indigenous cinema. Cultural pedagogies. Ethnic and racial relationships.

\section{Pedagogia Culturale dei Cineasti Mbyá-Guarani}

\section{RIASSUNTO}

II cinema indigeno è stato plasmato da una vasta gamma di narrazioni cinematografiche la cui realizzazione deriva dall'azione diretta di membri di diversi gruppi etnici indigeni brasiliani, con il sostegno di istituzioni incentrate sulla produzione audiovisiva autoriale. Molte di queste produzioni sono state premiate e proiettate in Brasile e all'estero, a volte accompagnate da sessioni di dibattito con i registi e gli stessi registi. Considerando che il cinema indigeno dinamizza l'estetica singolare, segnata dai modi di pensare e narrare un popolo indigeno, questo testo si concentra su narrazioni cinematografiche realizzate da membri del popolo Mbyá-Guarani nell'ambito del progetto Video in the Villages. L'obiettivo è analizzare i significati di territorialità costituiti nei film "Desterro Guarani" e "Tava, la casa di pietra", dai cineasti Mbyá-Guarani Patrícia Ferreira (Keretxu) e Ariel Duarte.

Cinema indigeno. Pedagogie culturali. Relazioni etnico-razziali.

\section{Pedagogías culturales en los logros de los cineastas Mbyá-Guaraní}

\section{RESUMEN}

El cine indígena se ha formado a partir de una amplia gama de narraciones cinematográficas cuya realización es el resultado de la acción directa de miembros de diferentes grupos étnicos indígenas brasileños, con el apoyo de instituciones enfocadas en la producción audiovisual autoral. Muchas de estas producciones han sido premiadas y proyectadas en Brasil y en el extranjero, a veces acompañadas de sesiones de debate con los propios cineastas y directores. Teniendo en cuenta que el cine indígena dinamiza la estética singular, marcada por las formas de pensar y narrar a un pueblo indígena, este texto se centra en las narraciones cinematográficas realizadas por miembros del pueblo mbyá-guaraní dentro del alcance del proyecto Video nas Aldeias. El objetivo es analizar los significados de territorialidad constituidos en las películas "Desterro Guarani" y "Tava, a casa de pedra", de los cineastas Mbyá-Guarani Patrícia Ferreira (Keretxu) y Ariel Duarte.

Cine indígena. Pedagogías culturales. Relaciones étnico-raciales. 


\section{Palavras Iniciais}

No presente artigo, analisamos pedagogias culturais que se constituem no que se tem chamado de cinema indígena - um conjunto de narrativas fílmicas cuja realização resulta da ação direta de membros de distintas etnias indígenas brasileiras, com apoio de instituições voltadas para a produção audiovisual autoral. Entendemos que, nos filmes produzidos por indígenas, dinamizam-se estéticas singulares e modos de narrar próprios de cada etnia envolvida na constituição desse tipo de material audiovisual. Desse modo, sob o olhar daqueles que assistem essas produções operam pedagogias que colaboram para educar e para expandir formas de pensar a territorialidade, a pertença étnica, a espiritualidade, a complexidade dos saberes do cotidiano indígena.

O conceito de pedagogias culturais diz respeito aos múltiplos lugares em que se produzem conhecimentos, em que se traduz e se representa a experiência e em que se consolidam verdades sobre coisas, sujeitos e acontecimentos (GIROUX; MCLAREN,1995; STEINBERG, 2015), Pode-se dizer, também, que há intencionalidade pedagógica nos diferentes lugares onde se constroem e se disputam representações, pois também aí o poder é organizado e difundido. Assim, os filmes de cineastas indígenas operam pedagogicamente ao constituírem certos lugares de fala, ao divulgarem formas de pensar e de viver de uma dada coletividade e ao contestarem estereótipos usualmente propagados em produções culturais sobre os distintos povos que tradicional e contemporaneamente habitam este território. Entendemos, também, que as produções autorais indígenas no cinema participam de um amplo conjunto de ações políticas, implicadas com a luta pela garantia da vida, da terra, dos direitos constitucionais e dos modos específicos de vida de cada etnia.

\section{Sobre as produções de cinema indígena analisadas neste texto}

São analisadas, neste estudo, narrativas cinematográficas feitas por membros do povo Mbyá-Guarani ${ }^{4}$, produzidas no âmbito do projeto Vídeo nas Aldeias, criado em 1986 e precursor na área de produção audiovisual indígena no Brasil. Desde o início - quando surgiu como um experimento realizado por Vincent Carelli e vinculado ao Centro de Trabalho Indigenista (CTI) - o projeto Vídeo nas Aldeias visava apoiar as lutas dos povos indígenas, colaborando para o registro de seus bens culturais, conforme

\footnotetext{
${ }^{4}$ Uma das parcialidades do povo guarani, do Tronco Tupi. No Brasil, atualmente os povos indígenas são classificados em quatro grupos linguísticos: Tupi, Macro-Jê, Aruak e Karib.
} 
indicações constantes em seu site ${ }^{5}$. A primeira experiência se desenvolveu na aldeia Nambiquara ${ }^{6}$ e, ao perceber o potencial deste recurso e a receptividade na exibição das filmagens entre os próprios indígenas, Carelli decidiu levar essa experiência a outros povos. Em 1997, realizou-se uma oficina de formação audiovisual na aldeia Xavante ${ }^{7}$ de Sangradouro e, desde então, são promovidas capacitações para indígenas que desejam participar do projeto e produzir vídeos. Em 2000, Vídeo nas Aldeias se constituiu como Organização não Governamental independente, e o trabalho desenvolvido até o momento possibilitou a criação de um importante acervo de imagens sobre os povos indígenas no Brasil, e um catálogo com mais de 70 filmes, a maioria deles premiados em festivais de cinema nacionais e internacionais.

Sobre o projeto Vídeo nas Aldeias, Araújo (2015, p. 22) afirma:

No decorrer dos seus 28 anos de existência, o VNA tem uma intensa atividade de realização cinematográfica junto a 37 povos indígenas do Brasil. Atua como uma escola de cinema para os povos indígenas através de oficinas de formação em audiovisual realizadas nas aldeias e na sede do projeto, em Olinda, no estado de Pernambuco. Desempenha também um papel fundamental como entidade responsável pela captação de recursos, produção e distribuição dos documentários. O projeto VNA possui um arquivo bruto de cerca de sete mil horas de material gravado, 87 filmes produzidos, inúmeros prêmios conquistados em festivais de cinema no Brasil e no exterior e, em particular, entendo que sua maior conquista se expressa na formação de inúmeros cineastas indígenas de diferentes etnias brasileiras. Para citar apenas alguns, acredito que se destacam notadamente os nomes de Ariel Ortega, Divino Tserewahú, Takumã Kuikuro, Valdete Ashaninka e Zezinho Yube.

Tal como afirmam Gallois e Carelli (1995, p. 62), o projeto Vídeo nas Aldeias foi "concebido como um programa de intervenção direta, [e] parte da premissa de que as identidades indígenas são, hoje, mais disseminadas que exclusivas, construídas a partir de tradições fragmentadas e, sobretudo, a partir da assimilação de influências transculturais". E os autores prosseguem:

\footnotetext{
${ }^{5}$ Informações constantes no site do Projeto http://www.videonasaldeias.org.br/2009/index.php.

${ }^{6}$ Os Nambikwara, também chamados de Cabixi, Nambiquera ou Nambiquara, são um povo indígena localizados no atual território brasileiro, no oeste do Mato Grosso e em Rondônia. Sua população soma menos de 3000 indivíduos Sua língua pertence à família Nambikwara. ${ }^{7}$ Xavante é um povo indígena que se autodenomina A'uwe ("gente") ou A'wẽ Uptabi ("povo verdadeiro"), e na classificação de línguas, integra a família linguística Jê, a qual, por sua vez, pertence ao tronco linguístico Macro-Jê. Sua língua é chamada Akwén. A população Xavante soma aproximadamente 15.500 indivíduos distribuídos em terras indígenas localizadas no leste do estado de Mato Grosso e Goiás.
} 
O projeto pretendia contribuir a esse movimento, colocando à disposição de povos indígenas a oportunidade de um diálogo adaptado a suas formas de transmissão cultural. $O$ objetivo era tornar acessível o uso da mídia vídeo a um número crescente de comunidades indígenas, promovendo a apropriação e manipulação de sua imagem em acordo com seus projetos políticos e culturais. $O$ vídeo representa, de fato, um instrumento de comunicação e um veículo de informação apropriado ao intercâmbio entre grupos que não só mantêm tradições culturais diversas, mas desenvolveram formas diferenciadas de adaptação ao contato com os brancos. (GALLOIS; CARELLI, 1995, p. 62).

Com o passar do tempo, esse projeto implantou uma rede de videotecas e centros de produção de vídeos em mais de duas dezenas de aldeias. A sede, em São Paulo, opera como centro de edição, duplicação e redistribuição tanto do material produzido pelos índios como pela equipe do programa. Conforme Dobal e Gonçalves (2018, p. 284):

Assim como acontece no projeto Vídeo nas Aldeias, a maior
parte dos cineastas indígenas atuais teve sua formação por
meio da participação em cursos de linguagem audiovisual
ministrados por não indígenas dividido em três etapas: a)
formação teórica; b) gravação para potencializar os
conhecimentos adquiridos na teoria; c) edição das imagens
(...) Após o curso, são fornecidos a eles os materiais técnicos
tais como câmeras e microfones para a produção de filmes
enquanto cineastas. A forma através da qual o indígena
tomou conhecimento da linguagem audiovisual, a liberdade
que ele tem de subvertê-la ou reconstrui-la estética ou
narrativamente é um ponto importante para se repensar o
protagonismo.

Podemos entender, a partir do exposto, que há um trabalho coletivo sobre o material filmado por cineastas e realizadores indígenas. Nesse sentido, a produção final não é expressão de um pensamento unicamente indígena - ele se constitui no atravessamento de técnicas, de sentidos, de representações e de maneiras de entender a produção audiovisual que define tanto o olhar das equipes do projeto que assessoram os indígenas, quanto dos realizadores de diferentes etnias. Trata-se, assim, de um tipo de produção intercultural. Concordamos com Dobal e Gonçalves (2018, p.283), quando argumentam que:

O modo como cada povo apreende e se apropria dos recursos audiovisuais para o registro de sua cultura evoca a percepção deles sobre eles mesmos e a forma através da qual desejam ser vistos. Tal percepção acontece não só no 
nível simbólico, mas também no afetivo e interétnico, resultando em inúmeros encontros de povos que não se conheciam, pois as suas narrativas orais ganham visualidade e uma temporalidade para além do espaço de enunciação. $A$ escolha do mito a ser representado, do costume, do ritual ou qualquer aspecto a ser filmado é algo que incide diretamente naquilo que o grupo pensa sobre si e no que deseja que se pense sobre ele, pois se apropriam de suas próprias imagens enquanto realizadores e produtores de imaginários.

A opção, feita neste estudo, de analisar a produção de cineastas Mbyá-Guarani diz respeito a um interesse em deslocar o lugar privilegiado de fala e de representação, já que, na maioria dos produtos culturais que circulam na atualidade, as narrativas são construídas sobre os povos indígenas (não são narrativas destes). Os filmes selecionados incorporam olhares de cineastas indígenas que manipulam as câmeras, definem os ângulos das tomadas, selecionam ambientes, travam conversas com pessoas das aldeias, colaboram na criação do roteiro, bem como na seleção e edição de imagens, na divulgação, entre outros aspectos. Como argumenta Araújo (2015, p.21), "no caso específico dos povos indígenas, os quais historicamente sempre foram objeto da mirada de antropólogos, cineastas e jornalistas, frequentemente ávidos por imagens exóticas de locais distantes, as novas tecnologias da informação e comunicação possibilitaram-lhes justamente inverter essa relação". Tem-se, assim, um amplo conjunto de possibilidades para pensar nos sentidos preferenciais, postos em circulação nestes materiais que, em muitos aspectos, confrontam e subvertem representações simplistas, restritivas, estereotípicas das culturas indígenas.

O caráter pedagógico do cinema é reiterado pois, ele educa quando produz e faz circular imagens, mensagens, representações, quando faz circular certos saberes, certas formas corporais, certos padrões de conduta. E o cinema ensina quando nos apresenta o outro, quando restringe ou amplifica nossas possibilidades de pensar como são e como vivem as outras culturas e povos com os quais não temos proximidade ou convivência. Tratamos as produções abordadas neste texto como cinema indígena, mas é relevante afirmar que elas se aproximam do que o Ocidente concebe tradicionalmente como gênero documentário. Esse gênero conjuga e coloca em jogo o que é visto como "real" e o que é visto como "ficção". Ele é o gênero fílmico que se caracteriza como oposto à ficção, de uma maneira semelhante ao modo como a fotografia se opunha à pintura no século XIX. Dessa forma, o documentário tem como pretensão afirmar-se como uma testemunha do mundo tal como ele é: as lentes da câmera teriam o objetivo de funcionar como o olhar do próprio espectador que percorre a cena, o espaço, o campo de exibição que o filme apresenta.

O acervo de Vídeo nas Aldeias conta com 9 produções de cineastas Mbyá-Guarani, mas neste texto são consideradas apenas duas delas: 
Desterro Guarani" e "Tava, a casa de pedra", ambas dos realizadores/cineastas Mbyá-Guarani Patrícia Ferreira (Keretxu) e Ariel Duarte Ortega. A tabela a seguir apresenta dados sobre elas:

Tabela 1: Ficha técnica dos filmes

\begin{tabular}{|c|c|}
\hline Título do Filme & Desterro Guarani \\
\hline Descrição & $\begin{array}{l}\text { Ariel Ortega faz uma reflexão sobre o processo histórico do contato } \\
\text { dos Mbyá-Guarani com os colonizadores, e tenta entender como seu } \\
\text { povo foi destituído de suas terras. }\end{array}$ \\
\hline $\begin{array}{l}\text { Realizadores } \\
\text { Indígenas }\end{array}$ & $\begin{array}{l}\text { Patricia Ferreira (Keretxu) - Guarani-Mbyá - e Ariel Duarte Ortega - } \\
\text { Guarani-Mbyá }\end{array}$ \\
\hline $\begin{array}{l}\text { Direção, Imagem e } \\
\text { Som Direto }\end{array}$ & Ariel Duarte Ortega e Patricia Ferreira (Keretxu) \\
\hline $\begin{array}{l}\text { Direção e } \\
\text { Fotografia }\end{array}$ & Vicent Carelli e Ernesto Ignacio de Carvalho \\
\hline Duração & $38 \mathrm{~min}$. \\
\hline Ano & 2011 \\
\hline Região & Acre \\
\hline Línguas & Guarani e Português \\
\hline Cor & Colorido \\
\hline Som & Estéreo \\
\hline Formato de Tela & $4 / 3$ \\
\hline Legendas & Espanhol, Francês, Inglês, Português \\
\hline Prêmios & $\begin{array}{l}\text { Menção Honrosa no FICA, Festival Internacional de Cinema } \\
\text { Ambiental, Goiás, Brasil, 2011. }\end{array}$ \\
\hline Título do Filme & TAVA, a casa de pedra \\
\hline Descrição & $\begin{array}{l}\text { Memória oral dos Mbyá-Guarani sobre as reduções jesuíticas e a } \\
\text { guerra guaranítica do século XVII no Brasil, Paraguai e Argentina. }\end{array}$ \\
\hline Equipe VNA & Ernesto Ignacio de Carvalho e Vicent Carelli \\
\hline $\begin{array}{l}\text { Realizadores } \\
\text { Indígenas }\end{array}$ & $\begin{array}{l}\text { Patricia Ferreira (Keretxu) - Guarani-Mbyá - e Ariel Duarte Ortega - } \\
\text { Guarani-Mbyá }\end{array}$ \\
\hline $\begin{array}{l}\text { Direção e } \\
\text { Fotografia }\end{array}$ & $\begin{array}{l}\text { Vicent Carelli, Patricia Ferreira (Keretxu), Ariel Duarte Ortega e } \\
\text { Ernesto Ignacio de Carvalho }\end{array}$ \\
\hline Edição & Tita (Tatiana Soares de Almeida) \\
\hline Duração & $78 \mathrm{~min}$ \\
\hline Ano & 2012 \\
\hline Região & Brasil e Argentina \\
\hline Línguas & Guarani e Português \\
\hline Cor & Colorido \\
\hline Som & Estéreo \\
\hline Formato de Tela & $16 / 9$ \\
\hline Legendas & Espanhol, Inglês, Português \\
\hline
\end{tabular}

Fonte: autor.

\section{Significados de territorialidade no cinema Mbyá-Guarani}

Discorrendo sobre as noções de territorialização e de territorialidade, Oliveira (1998) afirma que o primeiro termo diz respeito a um processo deflagrado por uma instância política, e tem relação, por exemplo, com a fixação de uma dada população e um determinado espaço geográfico. 
Territorialidade, por sua vez, refere-se a um estado ou qualidade inerente a cada cultura. Esta noção é utilizada, conforme o autor, por geógrafos franceses, e ela reforça vinculações atemporais a relação entre cultura e meio ambiente. Para Gallois (2004), territorialidade é um modo de valorizar a historicidade das relações de um povo indígena com a terra, bem como dos elementos culturais em jogo quando se fala das práticas de ocupação e gestão territorial.

As relações dos Mbyá-Guarani com os espaços de viver são dinâmicas e contextuais. Eles alteram, articulam, reinventam, agregam elementos de sua tradição e de tradições culturais de outros e movimentamse em um amplo território simbólico e material. As relações territoriais destes povos são também reconstruídas dentro das condições de nosso tempo. Tal como argumenta Viveiros de Castro (2017), a indianidade é um projeto de futuro e não uma memória do passado, e, desse modo, podemos pensar que todas as culturas indígenas se rearticulam dentro de condições particulares, no tempo presente, com vistas a sua existência no futuro - projetos de futuro implicam pensar o presente, considerar o que se tem em termos de experiências acumuladas e imaginar-se para frente, impulsionando com ações esse futuro sonhado.

Os Mbyá-Guarani ampliam suas redes de relações para obter aliados para as lutas, produzem o que é possível, dentro dos espaços ínfimos em que vivem ou das terras reconquistadas, e negociam com as comunidades circunvizinhas o que lhes falta. São bastante diversificadas as condições de vidas nas diferentes comunidades Mbyá. Mas nos acampamentos provisórios, que só no Rio Grande do Sul são abundantes e muitos se situam às margens de rodovias, a sobrevivência depende de uma rede tênue de serviços de saúde e, também de doações de alimentos, pois não há espaços para manutenção das formas próprias de organização produtiva. Ainda assim, com a precariedade que marca es formas de viver nesses espaços, não são menos importantes ou eficazes as maneiras de constituir e sustentar os sentidos de territorialidade pelos Mbyá-Guarani.

No filme Desterro Guarani (2011), exibe-se a jornada de Ariel Ortega, cineasta Mbyá-Guarani, percorrendo aldeias para compreender por que os Guarani têm tão pouca terra na atualidade, já que detinham vasta área territorial antes de iniciarem-se os ciclos de colonização europeia. Para isso, Ariel recorre aos anciãos Mbyá no Rio Grande do Sul e na Argentina e com eles dialoga. Desse modo, o filme vai mencionando migrações de populações Guarani e processos de expropriação territorial, e põe em relevo também a caminhada sagrada em busca da mítica Terra Sem Males, que hoje adquire a forma das migrações retratadas nas filmagens.

Em uma das cenas iniciais do filme, Mariano Mbyá-Guarani está em uma estrada de chão, em área rural, junto a outros poucos guarani, 
aguardando o ônibus. Ao fundo, pode-se vislumbrar uma placa de rodovia na qual há uma flecha indicativa e a inscrição "Aldeia Guarani”. O cineasta Ariel fala:

Será que, quando os brancos veem essa placa, eles pensam que a gente sempre esteve aqui neste mesmo lugar? Ou será que eles entendem que, muito antes dos avós deles chegarem, nós andávamos por esse vasto território, enquanto ele ainda era floresta?

A provocativa afirmação deflagra uma narrativa centrada no sentido de território. Há um corte na cena e vemos um grupo de pessoas Mbyá organizando uma exposição de objetos artesanais que serão vendidos aos que visitam o sítio arqueológico das Ruínas de São Miguel das Missões. Ariel aparece parcialmente na imagem e ouvimos a sua narrativa:

É que os brancos chegaram há muito tempo. E esses templos, as Tavas, são ruínas que se confundem com nossa história. Hoje, a gente vem até essa ruína pra vender artesanato, já que não temos terra para plantar e praticamente não existem matas.

$\mathrm{Na}$ produção deste filme, empregam-se estratégias para que o espectador acompanhe a cena como se dela participasse (o ângulo de tomada e a linha de filmagem, coincidindo com a do olhar, por exemplo), e, em alguns momentos adota-se recursos de metalinguagem, ocasiões em que podemos pode ver imagens do processo de edição do próprio filme. Nesse sentido, em uma sequência inicial, o cineasta Ariel Ortega está dentro de um estúdio audiovisual e esclarece:

Mas o que eu queria entender neste filme é por que quase não temos terra, se nós andávamos e habitávamos esse território antes dos brancos chegarem... e já que fomos nós que construímos essa Tava.

Sobre a situação territorial dos Guarani, Ariel afirma:

Depois da guerra, os guarani continuaram caminhando pela região, enquanto as fazendas foram se estabelecendo, e, de repente, tudo estava tomado... Não havia mais lugar para nós.

Um recorte de entrevista com o político rio-grandense Olívio Dutra, exgovernador do Estado, é apresentado e ele afirma que seus avós, que não eram proprietários de terras, tinham uma relação de compreensão e

${ }^{8}$ Os recortes orais dos filmes são apresentados em formato enquadrado para diferenciar das citações diretas de textos escritos. 
solidariedade com os índios locais, além de uma identificação mútua pela "pobreza" material. Foi por compreender o que significa estar alijado da terra que, conforme o ex-governador, ele se empenhou em comprar algumas terras para os Mbyá durante seu governo no estado do Rio Grande do Sul.

Um agricultor da região é também entrevistado. Esse afirma ser descendente dos Guarani e diz seus avós contavam histórias sobre um grupo indígena que transitava pela região, porém não eram chamados de Guarani pelos colonos locais, e sim de "bugres". Ele refuta a teoria que afirma que os Guarani abandonaram a região missioneira após a guerra afirmando que, de acordo com os relatos das histórias de sua própria família, estes nunca abandonaram a região, estavam sempre passando, às vezes atravessavam a fronteira para a Argentina, às vezes acampavam nas imediações das fazendas na região.

Inácio Kunkel, agricultor, descendente de alemães da região missioneira, identificado no filme como apoiador dos Guarani na área da saúde, afirma que, depois da derrota Guarani na Guerra Guaranítica, esses não foram mais reconhecidos como um povo, pois dispersaram-se pelos limites de seu antigo território para, desse modo, escapar de conflitos violentos. Ele afirma:

As famílias que estavam mais dispersas... era comum elas prestarem serviço para os agricultores na troca por alimento. Dessa forma, nós aprendemos... nascemos convivendo com os próprios índios sem saber que eram índios.

Em outro ponto do filme, uma cena exibe carros de famílias guarani entrando na balsa que realiza a travessia da fronteira entre Argentina e Brasil. Nessa cena, pode-se ouvir a voz do cineasta Ariel Ortega, que afirma:

Nós passamos a ficar em constante deslocamento pelos poucos espaços livres nesse território. Além de invisíveis, nos tornamos estrangeiros numa terra que sempre habitamos.

Na cena seguinte, o cineasta está no estúdio fazendo a edição das imagens e explica aos membros da equipe de edição:

Nós Guarani nunca dizemos que a terra é nossa. Por isso que sempre caminhávamos, e em alguns lugares ficávamos 5, 6 anos, depois íamos para outro lugar. É que o lugar deixado continua sendo uma aldeia e por isso acabamos voltando lá algum dia. Pros nossos avós, todo esse território é uma grande aldeia.

Na sequência, o espectador é conduzido novamente às cenas da terra Mbyá e, na balsa entre as fronteiras, abre-se o sentido de pertença que não 
se vincula (nem se restringe) a um único território nacional. Ao embarcarem em um ônibus, do outro lado da fronteira, o cineasta prossegue explicando:

Hoje, temos que usar documento para atravessar uma fronteira que nós nunca aceitamos. Em nossos filmes, sempre tentamos explicar uma coisa fundamental para o povo guarani, que é a caminhada sagrada. Por que ainda estamos caminhando... e por que nossos avós já caminhavam.

A noção de contínuo caminhar dos Guarani é reforçada na cena seguinte, em que o cineasta conversa com um ancião, em Varzinha, no Rio Grande do Sul. O karaí fala sobre a caminhada e a articula a um sentido ritual e sagrado:

Eu faço essa caminhada. Eu tento ver alguma coisa... um sinal de Nhanderu. Eu
quero ouvir as palavras dele. [Em outra aldeia, da região metropolitana de Porto
Alegre, uma Kunhã-karaí afirma] "Foi o meu finado tio que nos trouxe pra cá. Ele
recebeu um sinal de Nhanderu, e então viemos pra Guarita. Nhanderu tinha mostrado
onde havia mais javalis, por isso viemos pra Guarita." Um Karaí da mesma aldeia
afirma: "Eu meditei pra me salvar, por isso vim pra cá. Vim pra cá e perdi a minha
mulher. Faleceu uma das minhas filhas. Mesmo assim, eu não fui embora. Eu
medito... pra me iluminar e alcançar a morada de Nhanderu.

Em outro recorte do filme, um ancião Mbyá-Guarani, da região metropolitana de Porto Alegre/RS, conta:

Eu vim pra cá com o meu tio. Ele que me trouxe. Eu fique aqui, depois fui pra Coxilha, depois fui pro Arroio do Conde. Dali, os policiais me expulsaram, e eu fui preso. Por isso não ficamos lá, fomos para Passo da Estância. A gente ficou na beira da estrada. Ficamos assim por muito tempo, acampados. A gente ficou lá por 5 anos. [O cineasta Ariel passa então a transitar entre acampamentos Guarani na beira de rodovias e, enquanto se exibem essas imagens, fala]: $A$ imagem dos Guarani na beira da estrada se tornou uma coisa comum. Crianças atropeladas... fome... Foi por isso que começamos a lutar pela demarcação das terras que habitamos no passado. Mesmo sabendo que essa terra pertence somente a Nhanderu.

Emprega-se, ainda a estratégia de mostrar reportagens de jornais e telejornais que colocam em destaque aspectos da luta pela demarcação de terras indígenas, mostrado que a luta pela demarcação e garantia territorial não é recente para os Mbyá-Guarani no Rio Grande do Sul. O cineasta relata também a situação da aldeia em que reside:

Uma das áreas que reivindicamos é a aldeia onde moro, Koenju, perto das ruínas de São Miguel. E assim começamos a ocupar esse espaço, de onde saímos séculos 
atrás. Já que não podemos caminhar livremente por todo o território, assim podemos, pelo menos, transitar entre essas aldeias demarcadas.

Olívio Dutra, ex-governador do estado do Rio Grande do Sul, afirma em uma parte final do filme:

Todo esse território era propriedade indígena. As reduções jesuíticas ocupavam dois terços do que é hoje o território do Rio Grande [do Sul]. Qual é o percentual das terras indígenas, hoje, definidas pros índios?

A cena seguinte, em plano aberto, mostra uma área ampla, com mata e água e, à direita da imagem, um líder Guarani fala:

É essa a área que querem comprar pros guarani. Isso que a gente tá vendo de lá até aqui. Aqui é muito maior do que o lugar onde estamos hoje. Tem muito mais mata. Mais árvores frutíferas. Tomara que os deuses sensibilizem o chefe deles, pra comprarem pra nós.

Destaca-se, nesta fala, elementos que integram, um tekoá, lugares onde se pode realizar a vida Guarani, onde se poder ser Guarani precisam ter condições ambientais e espirituais. Ter terra coberta com vegetação, com mata, ter fontes de água, são algumas das condições para que uma área seja reconhecida como um tekoá. Nesse sentido, Bergamaschi (2005, p. 19), assim explica: "TEKO: revela, explica e regula todos os aspectos da existência, também expresso como 'modo de ser Guarani', 'sistema Guarani'. A vida Guarani existe como TEKO"; "TEKOÁ: lugar bom para o Guarani viver, para construir a aldeia Guarani. Espaço adequado para viver o TEKO”.

O filme mostra um Encontro Guarani ocorrido no ano de 2007, em São Miguel das Missões, Rio Grande do Sul. O tema principal do encontro foi a questão territorial. Apresenta-se, então, um recorte da fala de um Guarani, e este já começa questionando:

Quantos anos mais a gente tem que esperar pra conseguir um pedaço de terra? Nós temos direito à demarcação das terras e isso é muito importante para nós, pra que possamos seguir o caminho dos que estavam nas ruínas. Pra que nossos velhos e velhas nos ensinem a viver daquela forma outra vez. A gente não quer vender artesanato pra sempre! Porque isso não nos traz saúde e vida." [Outro Mbyá afirma] "Hoje, nós precisamos do que sobrou das matas. Pra que nossos velhos possam rezar, realizar cerimônias, rituais... o batismo das crianças.

Por meio destes fragmentos de movimentos, com teor político e reivindicatório, bem como de falas de líderes deste povo, a luta pela demarcação e garantia das terras, conforme assegura a Constituição Federal 
de nosso país, é representada e, deste modo, afirmada. Outro Encontro Guarani é apresentado no filme, ocorrido em 2011, também em São Gabriel/RS. As imagens são acompanhadas da seguinte fala do cineasta:

Não é de agora que começamos a falar sobre demarcação. Já faz muito tempo. Até
agora, nada do que a gente pediu foi feito." Outro Guarani fala: "Alguns de nós têm um
pouquinho de terra e os brancos podem nos dar mais. Mas eles nos dão sem
documento. Estamos numa aldeia que não tem documento garantido. E isso é direito
nosso.

Em outra cena, um Mbyá conta sobre os Encontros Guarani, o que confere maior coesão aos depoimentos apresentados:

Nesses encontros falamos sempre sobre isso. Mostramos para os que não sabem o lugar onde nosso guerreiro Sepé morreu, onde os nossos parentes morreram. Mostramos pros brancos e pros filhos deles, que ainda não desistimos.

O caráter de luta pela terra - que se dá pela argumentação, pelas tentativas de entendimentos e também pelas ações de transitar, caminhar, retomar partes do território encontram expressão nesta produção cinematográfica. Sobre a caminhada sagrada Guarani - a ritualística de transitar levemente, sem apegos, pelo território Guarani em busca da Terra Sem Males - o filme Desterro Guarani também opera produzindo uma narrativa localizada e contextual. Nele, um ancião Mbyá que reside atualmente em acampamento no município de Varzinha/RS comenta:

Eu faço essa caminhada. Eu tento ver alguma coisa... um sinal de Nhanderu. Eu quero ouvir as palavras dele. [um ancião da aldeia de Cantagalo explica]: Eu medito... pra me iluminar e alcançar a morada de Nhanderu.

Ao final do filme, exibe-se um grande grupo de guarani empreendendo uma caminhada em direção ao ponto em que se deu a morte de Sepé Tiarajuํ, um Karaí de Varzinha fala:

\footnotetext{
${ }^{9}$ Sepé Tiaraju, líder Guarani, foi morto na Batalha de Caiboaté, ocorrida em 10 de fevereiro de 1756, foi uma das mais sangrentas batalhas da Guerra Guaranítica, na qual cerca de 1.500 guarani foram mortos. A guerra foi motivada pela ação conjunta dos exércitos de Portugal e da Espanha para expulsar guarani que viviam em aldeamentos fundados pelos jesuítas espanhóis no atual estado do Rio Grande do Sul. Portugal e Espanha tinham assinado o Tratado de Madri, por meio do qual se propuseram a dividir o território da América do Sul entre si e as missões dos Sete Povos (que eram de jesuítas espanhóis) passou a pertencer aos território português. Liderados por Sepé Tiaraju, os Guarani se recusaram a entregar sua terra, com a qual possuíam (e possuem) vínculos de tradicionalidade.
} 
Por que será que estamos aqui? Por que será... que nós estamos aqui mais uma vez? Quando Nhamandu nos levanta... ele põe em nossa mente a sabedoria. Eu tô falando isso porque... estou chorando por dentro, vendo a nossa situação. Devemos seguir em frente. Mesmo nas piores condições... Porque nós temos Nhanderu a nosso favor.

A expressão "quando Nhanderu nos levanta" mobiliza um sentido cosmo-ontológico que orientaria a ação dos Guarani - seja ao retomarem um território, tendo o Karaí sonhado com ele, seja ao se reunirem ano após ano no local em que os Guarani sofreram um verdadeiro massacre, em 1756.

O contínuo caminhar Guarani é representado no filme Desterro, assim como a memória que, atualizada, constitui a pertença. Também no filme TAVA, a casa de pedra (2012), que possui várias muitas cenas idênticas ao filme Desterro Guarani, a dimensão territorial se expressa fortemente. Ariel e Patrícia, os cineastas Mbyá, viajam para a região missioneira da Argentina e, neste local, agregaram outras cenas que abordam as Tava no Rio Grande do Sul. No filme, a cineasta Patrícia aparece, percorrendo o sítio arqueológico da Redução de San Ignacio Miní, na província de Misiones, Argentina. Em seguida, os cineastas Ariel e Patrícia são apresentados em cenas na Aldeia Chapá, dos Guarani da província de Misiones, Argentina, e entrevistam uma jovem mulher Guarani que afirma:

Eu fui estudar na faculdade de Posadas pra tentar entender como era a vida dos Mbyá-Guarani no passado. Eu estudei Licenciatura em História. Mas descobri que a gente não estuda sobre a vida dos Guarani. Só estudamos sobre Roma e outros povos. Só sobre essas coisas. Me assustei com isso porque ao invés de eu aprender sobre a vida dos Guarani, eu aprendi dos brancos. Quando falam dos Guarani, eles dizem: Isso são apenas lendas, mitos... Falam isso e não dão valor. Porque não sabem a verdadeira história dos Mbyá.

Um ancião da aldeia complementa:

Eles nunca vão saber a verdade e, por conta disso, estão nos esquecendo. Eles querem saber da nossa história, mas não nos deixam contar, e depois dizem que não somos Guarani. Quando falam isso, os anjos escutam. Eles nunca deveriam falar essas coisas. [Ariel afirma]: Eles dizem que não foi o nosso povo que fez as ruínas... que não foram os Guarani. [O ancião prossegue]: Fomos nós, era o nosso trabalho. Éramos nós os que trabalhavam, meu jovem. Eles nos encontraram e queriam a nossa ajuda. Então construímos a Tava. É como juntar todas as crianças, pra saber as que vão ajudar e as que não. E então carregamos as pedras. Foi assim. Eles só querem saber de nós quando olham para as Tavas. Por que construímos? O que pensávamos? Se eram nossos antepassados mesmo... Ou se eram os outros... ou sei lá o que. Isso não é trabalho dos brancos. Isso começou lá no Paraguai e foi vindo pra cá. Nós é que somos donos de tudo isso aqui. Demos espaço a eles e agora se apoderaram de todo o território. As terras e as matas que vemos hoje foram deixadas pelo Kesuíta pra nós. O Sol segue iluminando o seu curso como um trem. Ele não é 
como a Tava. Ele só traz luz pra nós. A Lua também é assim. Ela e o Sol nos iluminam porque Kesuíta pediu. É assim, eles fazem como um favor a Kesuíta.

Em outra cena, o cineasta Ariel está em uma aldeia Mbyá do estado do Rio de Janeiro. Um ancião sai de sua casa cantando e fala, com olhar voltado para a câmera: "Sou realmente feliz por morar aqui." Então, eles se sentam em um tronco e iniciam uma conversa, enquanto tomam chimarrão e fumam o Petygua (cachimbo ritual). O ancião fala:

Eu já morei lá na aldeia do seu avô. Morei um tempo... Cresci por lá... Mas nunca fui
de sair muito. Porque meu pai não ia muito para a cidade. Ele gostava de morar no
mato. Naquele tempo, quando vim pra cá, não tínhamos nem documentos. Quando
nos viam sem documentos, duvidavam da gente. Mas Nhanderu iluminou nosso
caminho, por isso chegamos sem nenhum acidente. Nessa época eu ainda nem sabia
falar português.

Sentado ao lado do ancião, o cineasta Ariel também relembra acontecimentos e os relata:

Em 2007 começamos a fazer vídeos a favor dos Guarani. Não eram como os vídeos
feitos pelos brancos. Sempre quisemos mostrar a nossa Caminhada Sagrada, quem
construiu a Tava... Pra entender por que os Guarani não têm mais terras, e por que tá
tudo tão difícil. Durante este trabalho, fomos até a Argentina pra conversar com os
mais velhos sobre a Tava, a ruína. Lá na Argentina, nós vimos que os Guarani
precisam pagar pra entrar nas ruínas. Não podem transitar na morada dos
antepassados, não podem vender artesanato dentro nem fora... Os guardas nos
expulsam quando nos veem vendendo. Conversamos sobre isso com os mais velhos
de lá...

O caráter memorialístico que marca a cena prossegue quando uma mulher Guarani, que está sentada com o ancião e com o cineasta, explica:

Eu tinha um avô que falava sobre essas coisas. Não cheguei a conhecê-lo, mas sei o que se falava sobre esse assunto. Toda a verdade... Havia os nossos semideuses Nhanderu Mirim. Eles vieram... caminhando pela terra, vieram de longe, andaram tudo isso pra alcançar a Terra Sem Males. Junto com eles estavam nossos avós, que também meditavam. Eles seguiam os Nhanderu Mirim mesmo que não fossem com eles para a Terra Sem Males. Os Nhanderu Mirim vieram caminhando... Eles traziam consigo os seus javalis sagrados. Hoje, quando as crianças cantam, é em louvor aos Nhanderu Mirim e a seus javalis sagrados, que foram para a Terra Sem Males. Vieram todos, e pra isso construíram as Tavas. Construíram para morar lá por um tempo. Foi dali então que eles partiram para a morada de Nhanderu. Então depois que eles passaram, é verdade que deixaram as Tavas. E quando os brancos chegaram em grande número, como dizem nossos parentes, fizeram as Tavas de igreja e assim destruíram-nas. Destruíram tudo. Assim não pode ser! Lá em Paraty também tem Tava. Lá dá pra ver por onde passaram os javalis sagrados. 
Os recortes apresentados dos dois filmes - Desterro Guarani e Tava, a casa de pedra - mostram, por um lado, uma representação de mobilidade que tem relação tanto com condições objetivas - perda da terra para os projetos coloniais - quanto com dimensões sagradas, quando o caminhar é orientado por Nhanderu. Marcam-se, ainda, as formas tradicionais de ocupação territorial, formas de compreender os limites estabelecidos por fronteiras nacionais sobrepostas a uma concepção ampla de território Guarani. A memória - mobilizada nas palavras dos anciãos, mas também dos cineastas, vai constituindo imagens de uma cultura em constante reinvenção, mas que reafirma instâncias constitutivas - a palavra, o território, a mobilidade, por exemplo. Desse modo se representa o pensamento Mbyá como algo que se liga a um sentido de territorialidade, e que produz um "modo de ser Guarani" que se distingue de outras maneiras de ser, no mundo.

Autores como Clastres (2003), Melià (2004), Souza (2010), Bergamaschi (2005) já afirmaram que cultura Guarani se constitui num "contínuo caminhar", ou seja, se realiza na mobilidade nos limites de um amplo território (ancestralmente ocupado e para o qual há suporte mítico). Nos termos de Melià (2004), a mobilidade não diz respeito somente a um modo de relacionamento com a terra, mas constitui um nhande rekó, ou seja, um modo se ser particular, próprio, um modo de estar vivendo, uma lei abrangente que estabelece as formas da cultura. E a mitologia enlaça a vida cotidiana num caráter sagrado e estabelece, de maneira simbólica, parâmetros para pensar na criação do universo, do homem e de tudo o que o rodeia.

Ladeira (1994) explica que os mitos de origem orientam a organização social Guarani, as diferenciações entre grupos familiares, as chefias e as formas de espalharem-se no território tradicional. Ela destaca um depoimento Mbyá no qual se afirma:

Esse mundo não durará muito tempo. Meus filhos que vão estar no mundo vão ter que se separar. O mundo é muito grande. Por isso vão ter que se separar em, mais ou menos, três famílias, e deverão caminhar (ogata). Então, do começo do mundo (yvy apy) vieram andando, procurando seus lugares, seus verdadeiros lugares. Vieram do começo do mundo e andaram pela beira do oceano ( $y y$ ee remberupi meme) para encontrar o fim do mundo ( $y v y$ apy). (LADEIRA, 1994, p. 10).

Junto à dimensão sagrada desta ocupação, a autora afirma que existe uma funcionalidade, relativa, por exemplo, ao estabelecimento e manutenção de relações de reciprocidade social e política, formas de manutenção de relações com seu amplo território tradicional, cuidado com recursos naturais 
das matas. Se o território Guarani é sagrado para eles, essa é uma das razões para anciões e líderes espirituais Mbyá terem não só o direito, mas o dever de se pronunciar em ocasiões onde há mobilidade, quando os Guarani se põem a caminho - em especial quando o fazem coletivamente.

A ocupação territorial dos Guarani passa por um processo histórico de reelaboração do próprio sentido de território, conforme Pissolato (2004): se antes a ocupação era circular, gradativamente passa a assumir uma forma de uso descontínuo e sem fronteiras, dentro de um caminhar que incorpora novos espaços como estratégia de vida em tempos de massiva ocupação colonial. A população Mbyá está dispersa sobre um vasto território, e não há centralização, nem se pode falar numa articulação sistemática por comércio ou ritual entre as aldeias. Mas a autora argumenta que há articulações estratégicas, sustentadas na forma de organização social e no parentesco, por laços de consanguinidade e pelo casamento. A mobilidade Mbyá parece ter lugar central no funcionamento desta rede e na constituição da pessoa.

\begin{abstract}
A movimentação de pessoas entre localidades, às vezes muito distantes, confere ao sistema o seu dinamismo: aproxima ou afasta grupos familiares, funda novas localidades, cria redes de maior ou menor densidade de alianças. Circulação de pessoas entre aldeias/áreas já estabelecidas e deslocamento de grupos para a criação de novas localidades, estes são os dois movimentos que parecem fundamentais aí. [...] sugiro que o tema da movimentação de indivíduos e grupos entre os Mbya é lugar privilegiado de análise das sociocosmologias guarani, favorecendo tanto uma abordagem de princípios da organização social quanto da dimensão ritual e da função xamânica nesta sociedade. (POSSOLATO, 2004, p. 69-70).
\end{abstract}

A autora prossegue afirmando que os Mbyá empreendem dois movimentos básicos, sendo o primeiro concernente aos deslocamentos de grupos dentro de um amplo território (simbolicamente ocupado, que transcende as fronteiras nacionais) e o segundo concerne à circulação de indivíduos e grupos familiares entre locais de residência já estabelecidos (de modo que, na história de uma pessoa Mbyá, haverá muitos lugares de passagem). Esses dois movimentos compreendem o caminhar - numa dimensão organizativa e ritualística. Permitiriam, conforme a autora, a atualização das alianças, a resolução de conflitos, a expansão do campo socia, a atualização das práticas de reciprocidade.

Há sempre a expectativa de trocas humanas entre localidades mbya numa extensão tão grande quanto tornem possíveis as condições de trânsito entre elas; além das alianças matrimoniais, aspecto central deste sistema de 
trocas, a visitação/residência temporária entre localidades é o momento-chave da reprodução da memória e atualização, por parte de cada indivíduo ou grupo local, de seu campo social. A movimentação de pessoas permite que, de uma pequena aldeia no estado do Rio de Janeiro, um indivíduo se localize numa rede de relações que se estende por outras aldeias no mesmo estado, algumas em São Paulo, até o Paraná, e mais além. Seu universo social se estende na medida da memória de seu grupo familiar e de seu acesso à rede de trocas/visitas entre as diversas áreas. (PISSOLATO, 2004, p. 71).

Consideramos interessante, para reforçar nossa argumentação, colocar em destaque o depoimento de um ancião Guarani Kaiowá (embora de outra parcialidade, nos apresenta uma interessante vinculação da pessoa com a terra tradicional). Trata-se de parte do depoimento do ancião Guarani Kaiowá Feliciano Soares ${ }^{10}$ :

Na língua Guarani existe uma palavra ñemoyrõ, em Kaiowá ñemyrõ, que quer dizer tristeza, pranto, angústia, sentimento profundo que não vai passar, paixão, mágoa. É uma palavra usada para designar aquela dor de amor que não é correspondido. Ñemoyrõ é o sentimento de dor em relação ao sonho de viver em paz no tekoá, é o sentimento de amor pela terra que foi, por diversas vezes, violentamente expropriada, é a dor de um amor partido, um sentimento forte, lá dentro do peito, que parece que não vai passar nunca. (CIMI, 2006, p. 8).

É interessante pensar como, nos filmes aqui discutidos, a questão territorial é representada e como se expressa essa dimensão de sofrimento pela separação da terra. Viveiros de Castro (2017, p. 4). O autor defende que existe uma experiência compartilhada sobre o território que se estabelece de maneira semelhante entre os indígenas:

Ser indígena é ter como referência primordial a relação com a terra em que nasceu ou onde se estabeleceu para fazer sua vida, seja ela uma aldeia na floresta, um vilarejo no sertão, uma comunidade de beira-rio ou uma favela nas periferias metropolitanas. É ser parte de uma comunidade ligada a um lugar específico, ou seja, é integrar um 'povo'. [...] O indígena olha para baixo, para a Terra a que é imanente; ele tira sua força do chão. O cidadão olha para cima, para o Espírito encarnado sob a forma de um Estado transcendente; ele recebe seus direitos do alto.

${ }^{10}$ Esse depoimento, concedido ao professor indígena Adão Ferreira Benites da comunidade Ñanderu Marangatu, aldeia Campestre, município de Antônio João - MS, está publicado no "Relatório da violência contra os povos indígenas no Brasil" (CIMI, 2006). 
O antropólogo restitui a dimensão cosmo-ontológica à busca política pela garantia da terra. Sobre as lutas políticas, Brighenti (2010, p. 19) afirma que os Guarani evitam o confronto e ocupam o território à sua maneira. Em suas palavras:

O distanciamento do confronto é uma constante nos dias atuais, especialmente devido à fragmentação espacial, que os obriga a se deslocar em núcleos familiares, não conseguindo forças suficientes para enfrentar as situações adversas com terceiros. Esta perspectiva tende a ser temporária, pois, na medida em que se rearticulam socialmente, conseguem se impor politicamente sobre as situações constrangedoras, especialmente a falta de terras.

Ladeira (1994) também defende que os Mbyá não disputam terras, aspecto que se liga aos seus princípios espirituais (compartilhar o território e não o disputar é uma das premissas culturais). Por isso, segundo a autora,

A demarcação de terras não faz sentido em seu sistema.
Não é qualquer terra que lhes interessa; visam pontos
especiais num vasto território que histórica e socialmente
dominam. Não existe contradição. Se um certo desapego e
fragilidade quanto à permanência nas aldeias contrastam
com o propósito firme de caminhar à procura de lugares
especiais, isso acontece, ao contrário do que se poderia
supor, em razão do reconhecimento preciso e vivido do seu
território. A terra, ou os lugares que procuram, encontram-se,
ainda hoje, nos mesmos "limites" pré-estabelecidos pelos
antepassados míticos. A noção de terra está, pois, inserida
no conceito mais amplo de território que sabidamente pelos
Mbya se insere num contexto histórico (mítico) cíclico, e,
portanto, infinito, pois ele é o próprio mundo Mbya.
(LADEIRA, 1994, p. 13).

Ocorrem, na atualidade, muitas lutas por recuperação de porções de terra - contrariando a premissa cultural de resguardar-se do conflito e isso se deve, possivelmente, à escassez de terras e de recursos restantes para este povo. As lutas Mbyá não são de enfrentamento direto, mas se desenham de outras formas, como argumentei anteriormente. As retomadas de terra ação de resistência que se faz de modo silêncios - integram os atos de caminhar e a realização da busca pela Terra sem Males. As explicações para as retomadas e as formas de dar-Ihes sentido são fortemente sustentadas no pensamento cosmo-ontológico e nas práticas cotidianas dos Mbyá.

Podemos pensar, por fim, no modo como a territorialidade está implicada com um modo de ser de cada povo indígena. Tal narrativa seria constituidora do "modo como os grupos familiares traçam sua história através 
das caminhadas, recriando e recuperando sua tradição num 'novo' lugar, faz com que sejam portadores de uma experiência de vida e de sobrevivência também comuns" (LADEIRA, 1994, p. 12). A mobilidade entre aldeias e entre grupos mantém os Mbyá em contínuo caminhar que é, também, processo de reorganização social e de constituição de pertenças. Os filmes que apresentamos neste texto operam uma pedagogia ao exibirem de certos modos os vínculos entre os Mbyá-Guarani e a terra, e ao assumirem uma narrativa que parte da perspectiva de homens e mulheres que experienciam o contínuo caminhar e o viver singular Mbyá-Guarani.

\section{Palavras finais}

O cinema indígena opera como uma pedagogia cultural e convida-nos a revisitar distintos modos de pensar as coletividades indígenas - seu passado, seu presente, seus projetos de futuro. Pode-se dizer que o cinema indígena nos causa muitos estranhamentos - seja pelo modo como o filme mobiliza recursos e estratégias, entre o "real" e a "ficcionalidade", entre a linguagem e a metalinguagem, seja pela perspectiva que se abre ao nosso olhar, narrada com recursos culturais e palavras de outros. Podemos dizer que é por meio de um estranhamento radical que pode se realizar uma educação do nosso olhar: estranhamos os roteiros, as formas de edição, as histórias narradas; estranhamos a figura de um índio com uma câmera na mão (tecnologia exógena), capturando cenas em meio a uma floresta ou junto ao fogo aceso no interior de uma habitação de chão batido; estranhamos também imagens nas quais se desloca o indígena do espaço usualmente entendido como sendo seu "lugar natural", a transitar entre carros ou em áreas comerciais de grandes metrópoles.

Os filmes de cineastas indígenas operam pedagogicamente ao constituírem certos lugares de fala, ao divulgarem formas de pensar e de viver de uma dada coletividade, ao tornarem visíveis formas particulares de dar sentido às relações entre os seres, e destes com uma língua, com um território e com um universo de conhecimentos próprios e compartilhados. 0 cinema indígena funciona como pedagogia cultural, ainda, quando contesta e desloca estereótipos propagados em produções culturais sobre os indígenas e, desse modo, participa de uma rede mais ampla de ações, dentro do que se tem chamado de políticas da diferença. Os fragmentos apresentados e discutidos neste texto possibilitam um rearranjo de argumentos em torno do que entendemos por caminhar, o que entendemos por ter ou pertencer a uma terra, uma localidade, uma nação.

A incorporação de tecnologias exógenas à vida indígena (no caso específico do cinema, estamos falando de um conjunto amplo de novas 
tecnologias) não é um fenômeno recente. Basta pensarmos que a escrita como tecnologia de produção de memória e de registro - vem sendo incorporada por alguns povos, de modos variáveis, há séculos.

No atual contexto, o cinema interessa aos indígenas como produção híbrida, que pode ser apropriada para produzir histórias, memórias, narrativas, representações, imagens de uma vida que eles desejam dar a conhecer. Os cineastas de diferentes etnias vêm buscando entender como funcionam e como podem ser uteis essas tecnologias para a expressão de suas próprias formas de pensar o mundo, o espaço, o tempo, a arte, e, também, como estratégia para dominar o ritmo e a direção das mudanças que ocorrem, inevitavelmente, em qualquer cultura.

\section{REFERÊNCIAS}

ARAÚJO, Juliano José de. Cineastas Indígenas, Documentário e Autoetnografia: Um Estudo do Projeto Vídeo nas Aldeias. 2015. 270 f. Tese (Doutorado) - Curso de Multimeios, Universidade Estadual de Campinas, Campinas, 2015.

BERGAMASCHI, Maria Aparecida. Nhembo'e ¡Enquanto o Encanto Permanece!: processos e práticas de escolarização nas aldeias Guarani. 2005. 273 f. Tese (Doutorado). Curso de Educação - Universidade Federal do Rio Grande do Sul, Porto Alegre, 2005.

BRIGHENTI, Clovis Antonio. Estrangeiros na Própria Terra: Presença Guarani e Estados Nacionais. Chapecó/Florianópolis: Argos/EDUFSC, 2010.

CIMI. A violência contra os povos indígenas no Brasil - 2003-2005. Brasília: Conselho Indigenista Missionário, 2006.

CLASTRES, Pierre. A sociedade contra o Estado: pesquisas de antropologia política. São Paulo: Cosac Naify, 2003.

DOBAL, Susana Madeira; GONÇALVES, Josianne Diniz. Repensando o protagonismo: uma análise do filme "Karai Há'egui Kunhã Karai'ete - Os verdadeiros líderes espirituais" de Alberto Alvares. ECCOM, v. 9, n. 18, jul./dez. 2018.

GALLOIS, Dominique. Terras ocupadas? Territórios? Territorialidades? In: FANY, Ricardo. Terras indígenas e unidades de conservação da natureza - o desafio das sobreposições territoriais. São Paulo: ISA, 2004.

GALLOIS, Dominique; CARELLI, Vincent. Vídeo e diálogo cultural - experiência do projeto Vídeo nas aldeias. Horizontes Antropológicos, Porto Alegre, ano 1, n. 2, p. 61-72, jul./set. 1995.

LADEIRA, Maria Inês. Os índios Guarani/Mbya e o complexo lagunar estuarino de Iguape-Paranoá. Publicações do centro de Trabalho Indigenista, 1994. 
MELIÀ, Bartomeu. La novedad guaraní (viejas cuestiones y nuevas

preguntas). Revista bibliográfica (1987-2008). Revista de Índias, vol LXIV, n. 230, 2004, p. 175-226.

OLIVEIRA, João Pacheco de. Uma etnologia dos "índios misturados"? Situação

colonial, territorialização e fluxos culturais. Mana, Rio de Janeiro, v. 4, n. 1, p. 47-77, Apr. 1998. Available from

http://www.scielo.br/scielo.php?script=sci_arttext\&pid=S0104-

93131998000100003\&lng=en\&nrm=iso. Acesso em 16/02/2019.

PISSOLATO, Elizabeth. Mobilidade, multilocalidade, organização social e cosmologia: a experiência de grupos Mbya Guarani no sudeste brasileiro. Tellus, ano 4, n. 6, p. 65-78, abr. 2004.

SOUZA, Luiz Antônio Catafesto de. Crianças Mbyá-Guarani: Práticas educativas \& tecnologias de produção da pessoa. 2010.137 f. Dissertação (Mestrado) - Curso de Educação, Universidade Luterana do Brasil, Canoas, 2010.

STEINBERG, Shirley. Produzindo múltiplos sentidos - pesquisa com bricolagem e pedagogia cultural. In: KIRCHOF, Edgar R.; WORTMANN, Maria Lúcia C.; COSTA, Marisa V. Estudos Culturais \& Educação: contingências, articulações, aventuras, dispersões. Canoas: Ed ULBRA, 2015, p. 211-242.

VIVEIROS DE CASTRO, Eduardo. Os involuntários da Pátria. Elogio do subdesenvolvimento. Edições Chão da Feira (Caderno de Leituras / Série Intempestiva) n. 65, p. 109, maio de 2017. Disponível em:

https://chaodafeira.com/catalogo/caderno-n-65-os-involuntarios-da-patria/. 